\title{
Erratum to: Delayed Closure of Giant Omphaloceles in West Africa: Report of Five Cases
}

\author{
Oumama El Ezzi ${ }^{1} \quad$ Raymond Bossou ${ }^{2}$ Olivier Reinberg ${ }^{1} \quad$ Sabine Vasseur Maurer ${ }^{1}$ \\ Anthony de Buys Roessingh ${ }^{1}$
}

\footnotetext{
${ }^{1}$ Department of Pediatric Surgery, CURCP, Centre Hospitalier Universitaire Vaudois, Lausanne, Switzerland

2 Departement du zou et collines - Pediatry, Abomey, Benin

Eur J Pediatr Surg Rep 2018;6:e23.
}

\begin{abstract}
Address for correspondence Anthony de Buys Roessingh, MD, PhD, HDR, Department of Pediatric Surgery, CURCP, Centre Hospitalier Universitaire Vaudois, Lausanne 1011, Switzerland (e-mail: anthony.debuys-roessingh@chuv.ch).
\end{abstract}

\section{ERRATUM}

It has been brought to the Publisher's attention that the author's name "Sabine Vasseur Maurer" was not tagged correctly in the above-mentioned article, published in European J Pediatr Surg Rep vol 5, issue 1. DOI of the original article is $10.1055 / \mathrm{s}-0037-1599796$. The names should be listed with "Sabine" as first name and "Vasseur Maurer" as family name.

(c) 2018 Georg Thieme Verlag KG Stuttgart · New York
License terms

(c) (i) 